\title{
INOVASI MEDIA PEMBELAJARAN MATEMATIKA BERBASIS LAGU DI SEKOLAH DASAR
}

\author{
SURIYANA $^{1}$, SITI NUR ASMAH $^{2}$, DEDEK KURNIAWATI $^{3}$ \\ ${ }^{1}$ Universitas Nahdlatul Ulama Kalimantan Barat \\ suriyana@unukalbar.ac.id \\ ${ }^{2}$ Universitas Nahdlatul Ulama Kalimantan Barat \\ sitinurasmah@unukalbar.ac.id \\ ${ }^{3}$ Universitas Nahdlatul Ulama Kalimantan Barat \\ dedekkurniawati@unukalbar.ac.id
}

First Received: 02-04-2020; Accepted: 28-04-2020

\begin{abstract}
Abstrak
Penelitian ini merupakan penelitian pengembangan. Tujuan penelitian ini untuk mengembangkan media pembelajaran matematika berbasis lagu pada materi segitiga. Sedangkan kualitas media lagu matematika akan dideskripsikan meliputi kelayakan media lagu matematika, efektivitas media lagu matematika ditinjau dari hasil belajar siswa, dan respon siswa terhadap media lagu matematika. Model pengembangan penelitian ini menggunakan model pengembangan Thiagarajan yang terdiri dari 4 tahap yaitu: tahap pendefenisian (define), tahap perencanaan (design), tahap pengembangan (develop), dan tahap penyebaran (disseminate). Intrumen yang dilakukan dalam penelitian ini (1) lembar evaluasi untuk ahli materi, dan (2) lembar evaluasi untuk ahli media, kedua itu dinilai untuk kelayakan, (3) soal posttest atau lembar hasil belajar dan lembar angket respon siswa untuk efektivitas. Berdasarkan hasil evaluasi pengembangan media lagu matematika hasil evaluasi dari ahli materi memperoleh rata-rata skor 4 sedangkan hasil evaluasi dari ahli media memperoleh rata-rata skor 4, sehingga media lagu matematika dinyatakan layak. Hasil posttest menunjukkan bahwa persentase materi segitiga $80 \%$, ketuntasan. Sedangkan angket respon siswa sebesar 3,11 sehingga dapat disimpulkan bahwa media lagu matematika sangat efektif menumbuhkan minat belajar matematika. Dengan demikian dapat disimpulkan bahwa media lagu matematika yang dikembangkan memenuhi kriteria layak, efektif, dan praktis yang dapat digunakan sebagai bahan ajar yang baik.
\end{abstract}

Kata kunci: Inovasi; Media lagu; Matematika

\section{SONG INNOVATION IN MATHEMATICS LEARNING IN THE ELEMENTARY SCHOOL}

\begin{abstract}
This research is a development research. The purpose of this research is to develop song-based mathematics learning media on triangle material. Whereas the quality of the mathematics song media will be described as covering the feasibility of the mathematics song media, the effectiveness of the mathematics song media in terms of student learning outcomes, and student responses to the mathematics song media. The research development model uses the Thiagarajan development model which consists of 4 stages, namely: the defining stage, the design stage, the develop phase, and the disseminate stage. The instruments conducted in this study (1) evaluation sheets for material experts, and (2) evaluation sheets for media experts,
\end{abstract}


both of which were assessed for eligibility, (3) posttest questions or learning outcome sheets and student response questionnaire sheets for effectiveness. Based on the evaluation results of the development of the mathematical song media the evaluation results from the material experts obtained an average score of 4 while the evaluation results from the media experts obtained an average score of 4 , so the mathematical song media was declared feasible. The posttest results showed that the percentage of triangle material is $80 \%$, completeness. While the student response questionnaire was 3.11 so it can be concluded that the mathematics song media is very effective in growing interest in learning mathematics. Thus it can be concluded that the mathematical song media developed meets the criteria of feasible, effective, and practical which can be used as good teaching material.

Keywords: Innovation; Song media; Mathematics

\section{PENDAHULUAN}

Pembelajaran matematika adalah pembelajaran yang sangat penting dalam setiap jenjang pendidikan. Ilmu yang diajarkan pada pembelajaran matematika juga berperan besar dalam kehidupan sehari-hari. Sebagai pembelajar tentu akan menemukan pelajaran ini, baik dari jenjang pendidikan anak usia dini bahkan hingga pendidikan tinggi. Namun, pelajaran matematika ini dianggap sebagai satu di antara pelajaran yang sulit bagi kalangan pembelajar. Asumsi atau anggapan tersebut memberikan sugesti yang cukup besar sehingga berdampak pada lemahnya motivasi pembelajar dalam menerima materi yang berkaitan dengan matematika. Selain itu, juga berdampak pada hasil belajar peserta didik yang cenderung rendah.

Proses belajar yang menarik dan inovatif tentu akan mendukung hasil belajar yang optimal. Hasil belajar dalam hal ini merupakan tolok ukur untuk menentukan tingkat keberhasilan dalam mengetahui pemahaman terhadap pembelajaran. Dari laporan TIMMS (Trend in Mathematics and Science Study) 2011 yang dicuplik dari Murni (Untari dkk., 2017:93) bahwa prestasi matematika Pendidik Indonesia berada pada urutan ke-38 dari 42 negara dengan skor rata-rata turun menjadi 386. Hal tersebut menunjukkan bahwa hasil belajar matematika di Indonesia memprihatinkan.

Selanjutnya, peneliti juga melakukan prariset dengan mewawancarai guru kelas $\mathrm{V}$ di Sekolah Dasar Negeri 03 Pontianak Selatan. Berdasarkan hasil wawancara tersebut ditemukan bahwa kemauan peserta didiknya dalam belajar matematika masih sangat kurang, karena mata pelajaran matematika selalu berhubungan dengan rumus dan angka serta sering menghafal. Namun, dengan cara yang masih sangat konvensional. Sehingga peserta didik kurang bersemangat dalam mempelajarinya. 
Temuan lainnya pada saat observasi yaitu Guru Sekolah Dasar Negeri 03 Pontianak Selatan masih belum menggunakan media secara optimal terutama media berbasis teknologi dalam pembelajaran matematika. Padahal, media merupakan alat perantara yang penting untuk mentransformasi ilmu pengetahuan. Selain itu, dukungan fasilitas yang disediakan sekolah juga sudah memadai, sehingga tidak ada alasan untuk guru tidak menggunakan media berbasis teknologi. Masalah yang paling menonjol, yaitu kemampuan matematika yang berfokus pada materi bangun datar pada siswa SDN 03 Pontianak Selatan di kelas V yang tergolong rendah dan belum mencapai standar ketuntasan minimal. Adapun Kriteria Ketuntasan Minimal belajar mengajar (KKM) yang telah ditentukan yaitu 70. Sedangkan, dari hasil prariset nilai rata-rata siswa pada kemampuan matematika yang berfokus pada rumus keliling dan luas bangun datar yaitu 50. Siswa yang memperoleh nilai $>70$ atau tuntas berjumlah 11 orang dan siswa yang memperoleh nilai $<70$ berjumlah 20 orang.

Berdasarkan permasalahan tersebut peneliti berinisiatif mengembangkan media lagu pada pembelajaran metematika dengan memfokuskan pada rumus keliling dan luas bangun datar yaitu materi segitiga, Penelitian ini dilaksanakan karena mengingat pentingnya mengembangkan media pembelajaran lagu untuk mengatasi hafalan rumus, hasil belajar anak masih rendah serta untuk menambah referensi dalam inovasi pembelajaran.

\section{METODE PENELITIAN}

Metode dalam penelitian ini adalah pengembangan 4-D (Four D Model) yang terdiri dari 4 tahap: tahap pendefinisian (define), tahap perencanaan (design), tahap pengembangan (develop), dan tahap penyebaran (disseminate) media lagu matematika, sedangakan subjek dalam penelitian ini siswa SDN 03 Pontianak Selatan Kelas VA dan VB.

Metode dalam penelitian ini adalah metode pengembangan adapun langkah-langkah pengembangan yang dilakukan selengkapnya dibahas sebagai berikut: Secara garis besar keempat tahap tersebut sebagai berikut (Trianto, $2007: 65$ - 68), tahapan pertama pendefinisian (Define). Tujuan tahap ini adalah menetapkan dan mendefinisikan syarat-syarat pembelajaran diawali dengan analisis tujuan dari batasan materi yang dikembangkan perangkatnya. Tahap ini meliputi 5 langkah pokok, yaitu: (a) Analisis ujung depan, (b) Analisis siswa, (c) Analisis tugas. (d) Analisis konsep, dan (e) Perumusan tujuan pembelajaran. Tahap ke dua perencanaan (Design). Tujuan tahap ini adalah menyiapkan prototipe perangkat pembelajaran. Tahap ini terdiri dari empat langkah yaitu, (a) Penyusunan 
tes acuan patokan, merupakan langkah awal yang menghubungkan antara tahap define dan tahap design. Tes disusun berdasarkan hasil perumusan Tujuan Pembelajaran Khusus (Kompetensi Dasar dalam kurikukum K13). Tes ini merupakan suatu alat mengukur terjadinya perubahan tingkah laku pada diri siswa setelah kegiatan belajar mengajar, (b) Pemilihan media yang sesuai tujuan, untuk menyampaikan materi pelajaran, (c) Pemilihan format. Di dalam pemilihan format ini misalnya dapat dilakukan dengan mengkaji formatformat perangkat yang sudah ada dan yang dikembangkan di negara-negara yang lebih maju. Tahap ke tiga pengembangan (Develop). Tujuan tahap ini adalah untuk menghasilkan perangkat pembelajaran yang sudah direvisi berdasarkan masukan dari pakar. Tahap ini meliputi: (a) validasi perangkat oleh para pakar diikuti dengan revisi, (b) simulasi yaitu kegiatan mengoperasionalkan rencana pengajaran, dan (c) uji coba terbatas dengan siswa yang sesungguhnya. Hasil tahap (b) dan (c) digunakan sebagai dasar revisi. Langkah berikutnya adalah uji coba lebih lanjut dengan siswa yang sesuai dengan kelas sesungguhnya. Tahap yang ke empat penyebaran (Disseminate). Pada tahap ini merupakan tahap penggunaan perangkat yang telah dikembangkan pada skala yang lebih luas misalnya di kelas lain, di sekolah lain, oleh guru yang lain. Tujuan lain adalah untuk menguji efektivitas penggunaan perangkat di dalam KBM.

Instrumen penelitian ini digunakan untuk mengumpulkan data. Instrumen yang digunakan dalam penelitian ini lembar validasi, lembar observasi keaktifan siswa, dan lembar respon siswa. Lembar pedoman penelitian ada lembar validasi media lagu, lembar respon siswa, dan lembar soal evaluasi.

Teknik dalam pengumpulan data yaitu data kepraktisan media lagu matematika. Memberikan lembar validasi terhadap media lagu dalam pembelajaran matematika dengan 2 orang validator yang ahli media dan ahli materi. Teknik pengumpulan data keefektifan media lagu dalam kemampuan pembelajaran matematik dengan memperhatikan respon siswa terhadap media lagu dalam pembelajran matematika serta pemberian soal evaluasi.

Teknik analisis data penelitian ini adalah untuk mengetahui kepraktisan, keefektifan hasil belajar dari pengaplikasian media lagu pada pembelajaran matematika materi bangun datar. Analisis data dilakukan dengan cara sebagai berikut. (1). Analisis kelayakan, (2) Analisis keefektifan.

Instrumen pengumpulan data yang digunakan dalam penelitian dan pengembangan ini antara lain lembar validasi, lembar respon siswa, dan lembar penilaian soal evaluasi. Analisis data hasil penelitian dikategorikan analisis kelayakan, kepraktisan, dan keefektifan. 
Analisis kepaktisan atau kelayakan media lagu matematika ini dapat dilihat dari hasil validasi para pakar yaitu ahli materi dan ahli media. Mencari rata-rata aspek menggunakan rumus:

$$
P=\frac{\sum \text { Rata }- \text { rata, kriteria, } \text { pada, setiap, aspek }}{\text { banyaknya, kriteria, dalam, setiap, aspek }}
$$

Ket : P = Rata-rata aspek ke-1

Mencari rata-rata total validator (RTV) semua menggunakan rumus:

Ket $:$ RTV $=$ Rata-rata total validitas.

$$
R T V=\frac{\sum \text { Rata }- \text { rata, tiap, aspek }}{\text { banyaknya, aspek }}
$$

Menentukan katagori kevalidan dengan mencocokkan rata-rata total dengan kriteria kevalidan perangkat pembelajaran yaitu.

Tabel 1. Kriteria kevalidan

\begin{tabular}{cc}
\hline Interval Skor & Kategori Kevalidan \\
\hline $4 \leq \mathrm{RTV} \leq 5$ & Sangat Valid \\
$3 \leq \mathrm{RTV} \leq 4$ & Valid \\
$2 \leq \mathrm{RTV} \leq 3$ & Kurang \\
$1 \leq \mathrm{RTV} \leq 2$ & Tidak Valid \\
\hline
\end{tabular}

Analisis keefektifan media lagu pembelajaran matematika dapat dilihat dari hasil soal tes. Soal tes yang diberikan adalah posttest dan angket respon siswa. Hasil dari posttest soal tes akan dianalisis dengan bantuan SPPS guna untuk mengetahui keefektifan penggunaan media lagu dalam pembelajaran matematika.

Tabel 2. Skala Sikap

\begin{tabular}{cc}
\hline Rerata Skor Jawaban & Klasifikasi Sikap \\
\hline $3,58-4,33$ & Sangat Setuju (SS) \\
$2,72-3,47$ & Setuju (S) \\
$1,76-2,61$ & Tidak Setuju (TS) \\
\hline
\end{tabular}

\section{HASIL DAN PEMBAHASAN}

Media lagu matematika dikembangkan. Pada tahap ini peneliti merancang media sesuai dengan karakteristik dan kebutuhan siswa. Karekteristik siswa Sekolah Dasar yang masih senang bermain membuat peneliti mendesain media pembelajaran yang dapat meningkatkan motivasi belajar siswa. Peneliti menetapkan media pembelajaran didesain yaitu berupa intrumen lagu yang sesuai di kalangan anak usia di Sekolah Dasar agar dapat lebih mudah diterima. Selanjutnya, intrumen tersebut diisi dengan lirik berupa rumus materi matematika pembelajaran yang disesuaikan. Peneliti menetapkan instrumen musik yang digunakan yaitu 
materi segitiga dengan instrumen lagu "Balonku". Untuk instrumen lagu tersebut dimainkan oleh pemusik yang sengaja disewa agar mendapatkan hasil yang optimal.

Peneliti membuat kerangka isi/bahan pelajaran sesuai dengan buku ajar yang digunakan oleh guru di Sekolah Dasar maka dapat peneliti merancang lirik lagu matematika dimana peneliti menggantikan lirik lagu dengan rumus-rumus yang sesuai dengan buku ajar. Berikut ini rincian lirik lagunya.

$\begin{array}{cc} & \text { Lirik lagu materi segitiga } \\ \text { Instrumen lagu : Balonku ada Lima } & \\ \text { Karya } & \text { : Pak Kasur } \\ \text { Akulah segitiga } & \text { Segitiga sama kaki } \\ \text { Akulah segitiga } \\ \text { Segitiga siku- siku } \\ \text { Keliling segitiga } \\ \text { Jumlahkan semua sisi } \\ \text { Luasnya segitiga } \\ \text { Setengah alas kali tinggi }\end{array}$

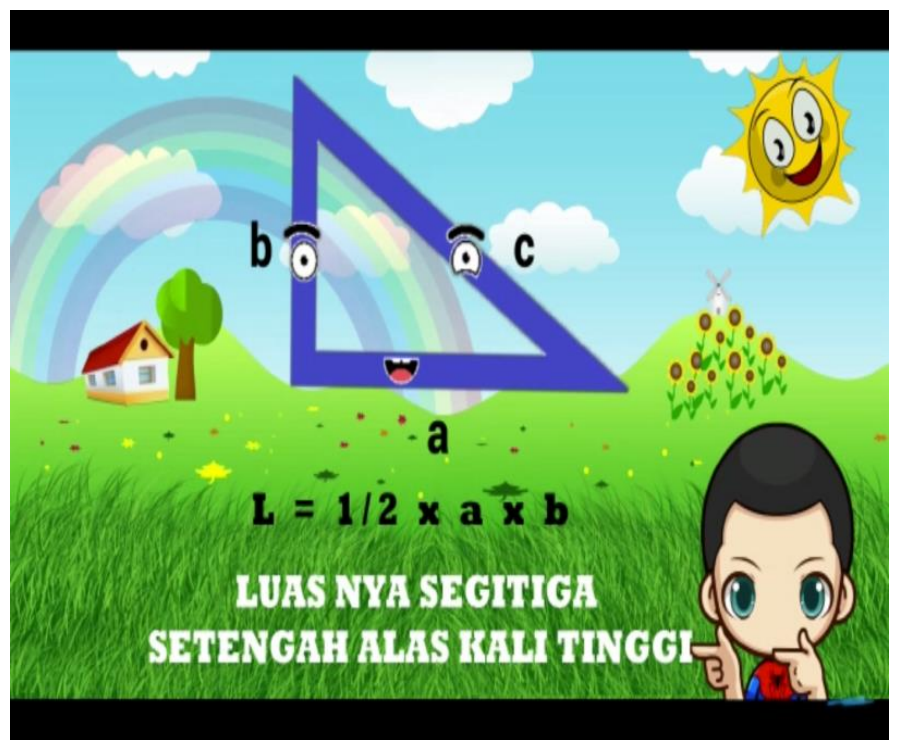

Gambar 1. Tampilan awal pembukaan media inovasi pembelajaran materi segitiga

Analisis kelayakan (Validasi) oleh ahli Materi dan ahli Media. Sebelum diuji coba media pembelajaran atau media lagu marematika terlebih dahulu divalidasi dua orang validator ahli materi dan ahli media. Dalam hal ini yang menjadi validator adalah dosen UNU Kalbar Prodi Pendidikan Matematika yaitu Boni Fasius Hery, S.Pd., M.Sc. dan Adha Maulana, S.ST.,M.T yaitu dosen UNU Kalbar Prodi Sistem Informasi. 
Adapun hasil penilaian validator rancangan awal pada media lagu matematika sebagai berikut: Hasil dari rata-rata penilaian para ahli terhadap rancangan awal media lagu matematika berada di bawah 3, ini berarti media pembelajaran berada pada kriteria kurang valid. Secara umum ahli menyatakan bahawa media lagu matematika yang dirancang dapat digunakan dengan melakukan banyak revisi.

Agar Media Lagu Matematika yang dirancang valid atau bisa digunakan, maka dilakukan revisi dengan memperhatikan komentar dan saran dari validator.

\section{Komponen Materi}

\section{Aspek Kelayakan Isi}

Komentar:

- Materi yang disajikan belum mencakup materi yang terkandung dalam Kompetensi Dasar (KD)

- Keluasan materi masih belum menjabar yang mendukung pencapaian (KD)

- Kegiatan dalam media lagu belum menumbuhkan kemampuan komunikasi sosial dan estetika siswa

- Kelengkapan materi yang disajikan

- Petunjuk dalam media lagu matematika masih belum nampak pada gambar untuk mendorong siswa mencari informasi lebih lanjut

\section{Aspek Penyajian}

Komentar:

- Orientasi siswa pada materi belum nampak untuk memulai dalam pembelajaran pada media lagu matematika

- Pada aspek mengorganisasi siswa lewat membuatkan kata pada materi masih belum disampaikan

- Pada aspek penyajian petunjuk untuk melakuan penyelesaian belum terlihat

- Pada aspek mengembangkan dan menyajikan hasil karya belum mengembangkan proses penyelesaian masalah

- Aspek menganalisis dan evalusi proses pemecahan masalah masih belum menggambarkan sesuai dengan kemampuan siswa

\section{Komponen Media}

\section{Aspek Perwarnaan}

Komentar: 
- Kombinasi warna masih belum sesuai

- Kesesuaian dari penyajian gambar dengan materi yang dibahas

\section{Aspek Pemakaian Kata dan Bahasa}

Komentar

- Dalam penggunaan bahasa masih belum baku, contoh pada kalimat dalam lirik lagu

- Kesesuaian bahasa masih belum sesuai dengan tingkat berpikir pada Sekolah Dasar

\section{Aspek Tampil Pada Layar}

Komentar

- Desain gambar masih belum sesuai dengan tingkat anak Sekolah Dasar

- $\quad$ Tipe huruf masih belum jelas

- Kesesuaian warna yang ditampilkan masih belum menarik

\section{Aspek penyaji}

Komentar

- Penyajian video masih belum menarik perlu ditambah tampilan gambar sesuai dengan tingkat Sekolah Dasar

- Penyajian media video belum dilakukan secara runtun

\section{Animasi dan Suara}

Komentar:

- Suara lagu dengan liriknya belum jelas

- Animasi antara video dengan suara masih belum tepat.

Dengan memperhatikan komentar dan saran validator terdapat komponen materi dan media dan aspek-aspek di dalamnya maka peneliti melakukan revisi terhadap aspek tersebut. Dengan upaya dalam melakukan revisi melihat dari saran dan komentar validator maka media lagu matematika layak digunakan dan dinyatakan valid.

Hasil analisis keefektifan dalam evaluasi pembelajaran. Berikut ini adalah data hasil belajar siswa setelah mengikuti pembelajaran dengan media lagu matematika.

Tabel 3. Hasil Evaluasi Pembelajaran

\begin{tabular}{lll} 
& \multicolumn{2}{l}{ Tabel 3. Hasil Evaluasi Pembelajaran } \\
\hline No & Nama siswa & Nilai \\
\hline 1 & A1 & 80 \\
2 & A2 & 40 \\
3 & A3 & 100 \\
4 & A4 & 100 \\
5 & A5 & 80 \\
6 & A6 & 80 \\
7 & A7 & 80 \\
8 & A8 & 60 \\
9 & A9 & 80 \\
10 & A10 & 80 \\
11 & A11 & 60 \\
\hline
\end{tabular}




\begin{tabular}{lll}
\hline 12 & A12 & 80 \\
13 & A13 & 40 \\
14 & A14 & 80 \\
15 & A15 & 100 \\
16 & A16 & 80 \\
17 & A17 & 100 \\
18 & A18 & 80 \\
19 & A19 & 80 \\
20 & A20 & 100 \\
Persentase (\%) & $80 \%$ \\
\hline
\end{tabular}

Analis Respon berikut ini adalah hasil perhitungan angket repon siswa terhadap pembelajaran media lagu matematika

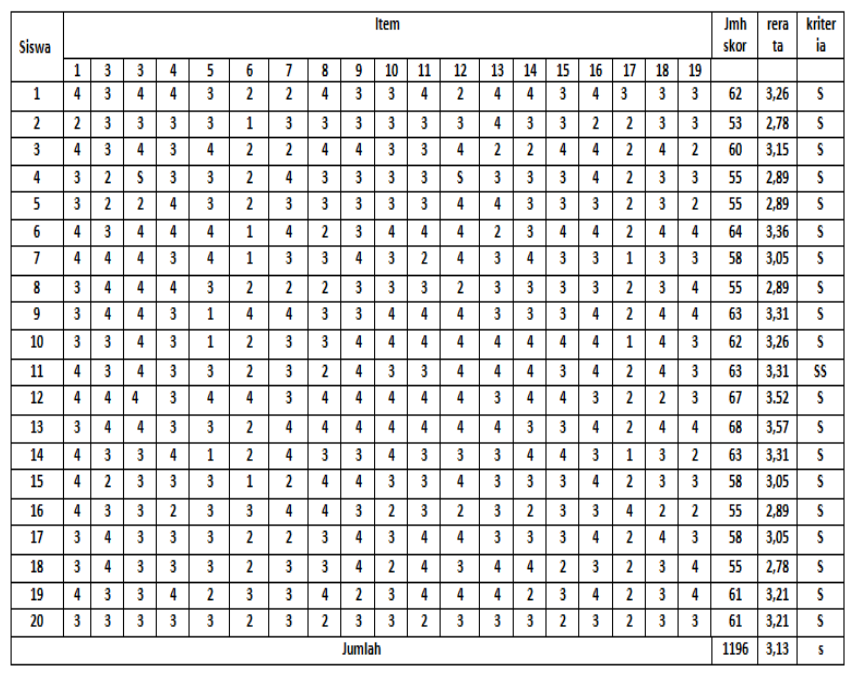

Gambar 2. Hasil Respon Siswa

Pembahasan dalam penelitian ini untuk menjawab permasalahan dalam membuktikan bahwa inovasi media lagu untuk berkontribusi dengan motivasi siswa terhadap pemebelajaran matematika. Penelitian ini sejalan dengan pendapat Handayati (2013) dalam penelitiannya yang berjudul "Keefektifitas Penggunaan Media Lagu dalam Pembelajaran Menulis Puisi Siswa Kelas IX SMP”. Peneliti tertarik bagaimana jika penelitian ini juga digunakan dalam pembelajaran matematika Sekolah Dasar. Sejalan juga dengan pendapat Purwanto (2011), dalam penelitiannya yang berjudul "Pengembangan Lagu Model sebagai Media Pendidikan Karakter Bagi Anak Usia Dini”. Berdasarkan kedua riset di atas, jelas sekali perbedaannya baik dari judul hingga pada substansi objek, materi dan sasaran yang diteliti.

Merujuk dari penelitian yang sudah ada serta melihat dari hasil penelitian secara menyeluruh terlihat bahwa inovasi media lagu yang telah dibuat sesuai dengan tahapantahapan yang terdiri dari 4 tahap yaitu dari 4 tahap: tahap pendefinisian (define), tahap perencanaan (design), tahap pengembangan (develop), dan tahap penyebaran (disseminate). 
Adapun tahapan-tahapan yang dilakukan peneliti. Tahap Pendefinisian (Define). Tujuan tahap ini adalah menetapkan dan mendefinisikan syarat-syarat pembelajaran diawali dengan analisis tujuan dari batasan materi yang dikembangkan perangkatnya. Tahap ini meliputi 5 langkah pokok, yaitu: Pada analisis awal akhir, pada tahap ini dilakukan analisis terdapat media pembelajaran yang berlaku di sekolah yang menjadi tujuan penelitian dan juga masalah mendasar yang menjadi acuan dalam pengembangan media pembelajaran dengan menggunakan media lagu Matematika. Dalam hal ini sekolah yang menjadi tujuan penelitian adalah SDN 03 Pontianak Selatan. Adapun kurikulum yang digunakan adalah kurikulum K13. Materi yang akan dijadikan untuk media lagu matematika adalah materi bagun datar yaitu materi segitiga.

Analisis siswa, dalam tahap ini peneliti melakukan diskusi bersama guru mata pelajaran diperoleh hasil karakter siswa. Dari kemampuan akademik cukup baik, tetapi untuk pembelajaran matematika hasilnya masih belum cukup baik, ketika ulangan harian dan ulangan umum masih banyak siswa yang perlu remidial. Guru pernah mencoba melakukan berbagai metode pembelajaran namun masih banyak siswa belum antusias dan ingin mau belajar dengan mendapat nilai yang kurang di bawah KKM. Untuk mengaktifkan siswa di tawarkan media pembelajaran menggunakan media lagu matematika yang disajikan dalam video lagu pembelajaran yang menarik untuk anak Sekolah Dasar, sehingga diharapkan ketika siswa dalam proses pembelajaran menggunakan media lagu matematika bisa menumbuhkan minat belajar matematika dan bisa meningkatkan hasil belajar.

Analisis konsep bertujuan untuk mengidentifikasi konsep-konsep yang utama yang dipelajari siswa dan disusun secara sistematis dalam peta konsep. Dengan metode studi pustaka, yaitu memperhatikan kurikulum K13 Sekolah Dasar di kelas 1V dihasilkan peta konsep bangun datar.

Analisis tugas, merupakan mengidentifikasi keterampilan-keterampilan utama yang diperlukan dalam pembelajaran yang sesuai dengan kurikulum K13 kemudian menganalisis ke dalam suatu kerangka sub keterampilan yang lebih spesifik. Berdasarkan analisis tugas untuk topik bangun datar diperoleh tugas-tugas sebagai berikut:

1. Tugas Umum

Siswa mampu menyelesaikan masalah yang berkaitan bangun datar yaitu kleiling dan luas bangun datar,

2. Tugas Khusus 
Tugas-tugas khusus yang dilakukan siswa dalam pembelajaran topik bangun datar adalah keliling dan luas bangun datar sebagai berikut:

a. Mengenal bangun datar, segitiga, segi banyak, jajar genjang

b. Mengetahui permaslahan yang berkaitan dengan matri bangun datar dalam kehidupan sehari hari

c. Menghitung rumus keliling bangun datar

d. Menghitung rumus luas bangun datar

\section{Perumusan tujuan pembelajaran}

Berdasarkan analisis tugas dan konsep diri dari materi bangun datar yang dapat disusun tujuan pembelajaran sebagai berikut :

1. Siswa dapat mengenal bentuk bangun datar termasuk bangun segitiga

2. Siswa dapat mengetahui permasalahan yang berkaitan dengan materi bangun datar dalam kehidupan sehari hari.

3. Siswa dapat mengetahui perhitungan rumus keliling bangun datar

4. Siswa dapat mengetahui perhitungan rumus luas bangun datar

Tahap perencanaan (Design), pada tahap ini dilakukan perancangan media lagu matematika yang dikembangkan. Dalam tahap ini dilakukan pemilihan media, pemilihan format dan desain awal.

Pemilihan media, pada penelitian ini merupakan memilih media lagu matematika yang akan dikembangkan dimana pada saat pengembangan lirik lagu anak-anak akan diganti dengan rumus keliling dan luas bangun datar.

Pemilihan format, pada langkah ini peneliti merumuskan format Media Lagu Matematika. Dalam mengembangkan media lagu Matematika memilih format yang sesuai dengan K13. Untuk format Video

Desain Awal, pada tahap ini dilakukan perancangan awal Media Lagu Matematika

Tahap pengembangan (Develop), tujuan dari tahap pengembangan adalah untuk merevisi media lagu Matematika yang dihasilkan pada tahap desain awal dengan memperhatikan masukan dari pada validator. Rancangan media lagu pembelajaran Matematika yang telah disusun pada tahap perancang materi Matematika dilakukan penilaian atau divalidasi dua orang validator yang ahli dalam bidang materi dan ahli dalam media dan mampu memberi masukan atau hasil saran untuk menyempurnakan media lagu matematika yang telah dirancanag videonya. Dalam hal ini yang menjadi validator adalah ahli materi 
dosen Pendidikan Matematika UNU Kalbar Bapak Boni Fasius Hery, S.Pd., M.Sc. dan ahli Media dosen Sistem Informasi Bapak Adha Maulana, S.ST., M.T.

Tahap penyebaran (Disseminate), pada tahap ini merupakan tahap ini peneliti penggunaan perangkat yang telah dikembangkan pada skala yang lebih luas misalnya di kelas lain, di sekolah lain, oleh guru yang lain.

\section{SIMPULAN}

Berdasarkan dari tujuan penelitan ini yaitu membuktikan bahwa inovasi media lagu untuk berkontribusi dengan motivasi siswa terhadap pembelajaran Matematika ke dua membuktikan bahwa inovasi media lagu sebagai referensi untuk mengembangakan aktivitas pembelajaran matematika, maka dapat disimpulkan sebagai berikut:

1. Berdasarkan validasi dari ahli materi dan ahli media, disimpulkan bahwa media lagu pembelajaran matematika dinyatakan kepratiksan adalah valid dan layak digunakan.

2. Hasil posttest (kemampuan akhir siswa) setalah menggunakan media lagu pembelajaran Matematika menunjukkan bahwa nilai hasil belajar siswa berhasil menunjukkan di atas rata rata KKM (Kriteria Ketuntasan Minimal) 75 dipersentasikan yaitu pada materi segitiga hasil nilai dengan $80 \%$, yang di atas kriteria ketuntasan.

Hasil angket respon siswa menunjukkan bahwa efektivitas dari penerapan media lagu Matematika dengan hasil yang didapatkan rerata skornya 3,11 menunjukan kriteria penilaian bahwa siswa setuju dengan sesuai katagori rentang $(2,72-3,47)$ Setuju.

\section{DAFTAR PUSTAKA}

Handayati, Wiwit, Syahrul R dan Afnita. (2013). Keaktifan Penggunaan Media Lagu dalamPembelajaran Menulis Puisi Siswa Kelas IX1 SMPN 5 Lubuk Basung. Jurnal Pendidikan Bahasa dan Sastra Indonesia. Vol. 1, No. 2: 226-232.

Hudojo. (2005). Pengembangan Kurikulum dan Pembelajaran Matematika..Malang; UM Press.

Purwanto, S. (2011) Pengembangan Lagu Model sebagai Media Pendidikan Karakter Bagi Anak Usia Dini. (tesis). Yogyakarta: UIN Sunan Kalijaga.

Sugiyono. (2014). Metode Penelitian Pendidikan. Bandung: Alfabeta.

Suherman, Erman dkk. (2003). Strategi Pembelajaran Matematika Kontemporer. Bandung: PT Remaja Rosdakarya. 
Sundayana, R. (2013) Media Alat peranga dalam Pembelajaran Matematika.Bandung: Alfabeta.

Trianto. (2011). Desain Pengembangan Pembelajaran Tematik Bagi Anak Usia Diri TK/RA \& Anak Usia Kelas Awal SD/MI. Jakarta: Kencana.

Widodo, Slamet. (2016). Pengembangan Lembar Kegiatan Siswa (LKS) Berbasis Pendekatan Saintifik Untuk Meningkatkan Keterampilan Penyelesaian Masalah Lingkungan Sekitar Siswa Kelas IV Sekolah Dasar. Tesis Magister Pendidikan: Unesa 